Ijtihad: Jurnal Wacana Hukum Islam dan Kemanusiaan

Vol. 21, No. 1 (2021), pp. 1-19, doi : 10.18326/ijtihad.v21i1.1-19

\title{
Legal reasonings of religious court judges in deciding the origin of children: a study on the protection of biological children's civil rights
}

\author{
Rohmawati \\ Institut Agama Islam Negeri (LAIN) Tulungagung \\ E-mail: rahma.ringinpitu@gmail.com
}

\author{
Ahmad Rofiq \\ Universitas Islam Negeri (UIN) Walisongo Semarang \\ E-mail:ahmad_rofig@walisongo.ac.id \\ DOI: 10.18326/ijtihad.v21i1.1-19
}

This study explores the extent to which religious court judges decided the origin of biological children following the implementation of the Indonesian Constitutional Court Decree number 46/ PUU-VIII/2010. A substantial ambiguity was apparent in the Indonesian family law concerning civil relationships between children born out of wedlock and their biological fathers. Consequently, judges had different legal interpretations over status of children, which created disparities of the children's civil right protection. This study focuses on investigating the judges' legal reasonings when deciding origin of biological children born out of wedlock. This is a case study with a legal philosophical approach. Data collection includes document collection, whereas data analysis involves deductive and inductive approaches. This study found three typologies of judges' legal reasonings in relation to how they decided the origin of the biological children. Pragmatic judges would not provide legal protection to the biological children as they failed to accept lineage of these children towards their parents, creating uncertainty over the children's legal status. Conservative judges with a positivistic mindset would acknowledge legal relationship between the biological children and their mothers, generating the children's civil rights in relation to their mothers. Progressive judges would provide legal protection to the biological children. Progressive judges accepted the lineage of these children towards their parents but acknowledged their civil rights in relation to their fathers in limited ways 
such as living allowance and testament. Disparities of judges' decisions regarding the origin of the biological children substantially created a legal uncertainty to these children.

Artikel ini mengkaji penetapan pengadilan agama tentang asal-usul anak biologis pasca Putusan Mahkamah Konstitusi Nomor 46/PUU-VIII/2010. Kesamaran substansi hukum mengenai hubungan perdata anak luar kawin dengan ayah biologis dalam hukum keluarga Indonesia telah mendorong hakim untuk melakukan penalaran hukum. Perbedaan penalaran hukum di kalangan hakim telah melahirkan disparitas perlindungan anak biologis. Pembahasan dalam artikel ini difokuskan pada penalaran hukum hakim tentang penetapan asal-usul anak biologis di pengadilan agama. Penelitian ini merupakan penelitian hukum dengan menggunakan pendekatan kasus dan pendekatan filsafat hukum. Pengumpulan data dilakukan dengan menggunakan teknik dokumenter. Sedangkan analisis data dilakukan dengan menggunakan logika deduktif dan induktif. Penelitian ini menghasilkan temuan adanya tiga tipologi penalaran hukum hakim dalam penetapan asal-usul anak biologis. Hakim pragmatis tidak memberikan perlindungan hukum kepada anak biologis karena mereka menolak pengakuan anak dari kedua orang tuanya, sehingga tidak adanya kejelasan status hukum bagi anak. Sedangkan hakim konservatif berparadigma positivistik, yaitu memberikan hubungan perdata anak biologis hanya dengan ibunya, sehingga hak-hak keperdataan anak biologis hanya dapat diperoleh dari ibunya. Adapun hakim progresif telah memberikan perlindungan hukum terhadap anak biologis secara proporsional, yakni mengabulkan permohonan pengakuan anak dari kedua orang tuanya dan memberikan hubungan perdata secara terbatas dengan ayahnya, berupa biaya hidup dan wasiat wajibah dari ayahnya. Disparitas putusan tersebut dapat menimbulkan ketidakpastian hukum bagi anak biologis.

Keywords: biological children; children's protection; judges' legal reasonings

\section{Introduction}

The Indonesian Constitutional Court Decree number 46/PUU-VIII/2010 lays foundation for a legal status of children born out of wedlock, in which these children are considered to have civil relationships with their biological parents. However, this Decree is problematic as several ambiguous statements are apparent. For instance, a statement which says, "children that are born out of wedlock" is not accompanied with a more detailed explanation. As such, one might assume that this statement refers to those children who are born by parents whose marriage are not legally reported (Sujono, 2015, p. 66; Marilang, 2016, p. 335). On the other hand, the other might think that these children are born by parents who committed adultery (Mokoginta, 2017, p. 105; Rosyad, 2017, p. 160).

The uncertainty of children's constitutional rights and the ambiguous definition of children born out of wedlock in this Decree, according to Simon Butt, has decreased 
legal protection and assurance for biological children (Butt, 2012). Ilma (2016, p. 133), in her thesis, showed that this Decree had not substantially impacted the effort to protect biological children. Additionally, biological children were considered to receive their rights for living only from their fathers.

Accordingly, Wahyudi (2017, p. 151) and Sarifudin, (2015, p. 106) state that protecting the civil rights of biological children needs to be based on the interest of the children. In other words, biological children should be seen as having equal civil rights as legal children, which include the right for their welfare, caregiving, inheritance, and guardianship. However, Nurlaelawati and Van Huis, (2019, p. 361) and Tobroni (2018, p. 324) oppose this idea. They specifically argue that equalizing the status and civil rights of biological children with those of legal children contradicts the concept of lineage as known in the Islamic law and undermine the sacredness of legal marriage.

Despite the ambiguous definition of children born out of wedlock in this Decree, religious courts are expected to actively take part in ensuring that legal protection regarding biological children are in place. This is reflected in the Act number 7/1989 about Religious Trial in which religious courts have an absolute authorization to decide the origin of children. That is, religious courts have the authority to provide a clear legal standing with regard to children's lineage status along with its civil rights. Notwithstanding, many religious courts have not been able to provide legal protection as needed due to different interpretations on the very definition of biological children that are born out of wedlock. Consequently, there are substantial disparities among religious court judges when deciding the legal status of these children.

On the one hand, these different judges' decisions are inevitable and can be justified as long as these are taken through fair and appropriate trials (Adji, 1984, p. 11). However, these different judges' decisions are also viewed as creating legal uncertainty and inequality. The different decisions made by religious court judges are closely related to their discrete systems of knowledge, which in turn influence their mindsets. For example, judges with a more positivistic mindset in practice will likely produce legal interpretations and decisions that are different from those with a more non-positivistic mindset (Indonesia, 2014, p. 12).

Existing studies which discuss the state regarding legal protection towards biological children mainly focus on two directions. The first direction tends to delve into investigating 
ljtihad: Jurnal Wacana Hukum Islam dan Kemanusiaan, Volume 21, No. 1, Juni 2021: 1-19

the origin of biological children with a particular attention on a specific decision made by an individual religious court judge (Tobroni, 2018). On the other hand, a number of studies focus their exploration more generally on several religious court judges which produce distinct decisions (Ilma, 2016). From these two directions, it is evident that there are disparities regarding judges' legal reasonings when deciding cases related to the status of biological children that are born out of wedlock. Nevertheless, studies which focus on investigating these disparities are very limited, if not unknown.

This study scrutinizes five legal decisions from five religious courts about the origin of biological children following the Indonesian Constitutional Court Decree number 46/ PUU-VIII/2010. The study includes legal decisions from: (1) Religious Court of Malang number 0316/Pdt.P/2015/PA.Mlg., (2) Religious Court of Central Jakarta number 0043/ Pdt.P/2014/PA.JP., (3) Religious Court of Banjarmasin number 0403/Pdt.P/2014/PA.Bjm., (4) Religious Court of Trenggalek number 0815/Pdt.P/2014/PA.TL., and (5) Religious Court of Magetan number 0078/Pdt.P/2014/PA.Mgt. These five religious courts were specifically selected because they reflected the disparities that this study is sought to investigate.

This study is aimed at scrutinizing the disparity of decisions found in five religious courts in Indonesia in ruling the origin of biological children. More particularly, this study problematizes the judges' legal reasoning methodology before making the decisions and classifies the typology of their reasoning. This study departs from a hypothesis that judges' different decisions might be influenced by their subjectivity in interpreting the relatively ambiguous statement stated in the above Decree.

\section{Methodology}

This study employs a case study approach and legal philosophical approach. Through a document collection method, the main data gathered include five documents which contain religious court decisions about the origin of biological children. In addition to these documents, this study also collects several supporting documents such as primary legal sources, secondary legal sources, tertiary legal sources, and non-legal sources. The main data analysis method in this study is deductive and inductive logical method in which the collected documents are compared, contrasted, and aggregated. 
Legal reasonings of religious court judges in deciding the origin of children: ...(Rohmawati, Ahmad Rofiq)

\section{The status of biological children in the Islamic family law in Indonesia}

The term biological children in the Islamic sharia refers to illegitimate children (walad al-zina). Al-Zuhaily (1985, p. 430) defines illegitimate children as those who were born by mothers whose pregnancy was not legitimate according to Islamic sharia, that is, the mothers committed adultery. In line with al-Zuhaily, a Fatwa (i.e., decision based on Islamic law) by MUI number 11/2012 describes illegitimate children as those who were born as a result of adultery - a criminal act (jarimah) - committed by their parents. From a different perspective, the term biological children are closely related to what Ibn Abidin mentions as actual children (al-waladun al-haqiqy). According to him, biological children are actual children as they inherit the sperm of their biological fathers (Abidin, 2003, p. 102).

In the Indonesian Civil Code, illegitimate children are categorized under children born out of wedlock. By employing argumentum a contrario in viewing the Law number 1/1974 Article 42, the term children born out of wedlock includes children born from unregistered marriages and children born from adultery. According to the writer, using the term biological children to refer to children born from adultery is more humanist and beneficial than using the term illegitimate children. Additionally, the term biological children is more commonly used by judges in legal trials regarding the origin of children.

In Indonesia, the legal status of a marriage determines the legal status of a child. Article 43 paragraph (1) of Marriage Law states that children out of wedlock only have a civil relationship with their mothers and their mothers' families. In the meantime, Article 100 of the Islamic Family Law uses the term lineage (nasab) to determine the civil relationship between children and their mothers. Conversely, the Constitutional Court Decree number 46/PUU-VIII/2010 regulates the civil relationship between children out of wedlock and their mothers and fathers. This Decree is intended to protect children's civil rights against irresponsible biological fathers and to minimize the act of adultery. Notwithstanding, this Decree is not without a flaw as several statements in this Decree are considerably ambiguous.

The Indonesia Ulema Council (here after MUI) issues a Fatwa number 11/2012 to define the legal status and the rights of illegitimate children. In general, this Fatwa emphasizes that illegitimate children, in relation to their biological fathers, are not entitled to essential 
ljtihad: Jurnal Wacana Hukum Islam dan Kemanusiaan, Volume 21, No. 1, Juni 2021: 1-19

civil rights such as lineage relationship, living allowance, guardianship, and inheritance. Nevertheless, to protect the civil rights of illegitimate children, this Fatwa regulates how the government can enforce punishment (ta'zir) to male adulterers in two ways: (1) they must fulfill their biological children's living cost, and (2) they must arrange inheritance for their biological children by writing a legal will (wasiat wajibah).

\section{The disparity of religious courts' decisions on the origin of children}

All trials regarding the origin of biological children in this study were all voluntary cases, where the trials were proposed by petitioners without any contenders. All these trials were specifically proposed by couples who had biological children from their committed adultery. After the birth of their children, they later got married legally and proposed legitimation to religious courts on behalf of their children for their legal status.

Indonesian religious courts in this study issued several regulations to determine the origin of biological children from parents whose marriage were legitimate. This implicates to at least three kinds of decisions towards biological children. First, a decision which illustrates the absence of legal protection towards biological children because the plea was rejected by the judge in the first place (See the Decision number 0316/Pdt.P/2015/PA.Mlg, 2015). The juridical implication from this rejection is that the biological children did not have a definite legal status. As such, these children were not entitled to any civil rights nor welfare from their biological parents.

The rejection also shows that the judge had put the biological children in a disadvantageous situation. In other words, the children's rights to receive a legal birth recognition was not considered, if not neglected, by the judge. Without a legal birth recognition, biological children did not hold a clear legal identity and status. Consequently, the children lost their access to basic needs such as education, healthcare, and welfare. In addition, such children were prone to sexual exploitation and harassment, human trafficking, and child marriage (Usma, 2019, p. 132). The rejection contradicts considerably with the child protection principle that has been stated in the 1945 Constitution, Human Rights Law, Child Welfare Law, and Child Protection Law. Additionally, the rejection does not comply with the Islamic sharia. That is, as literally stated in Quran, Sura al-Isra' verse 31, Islam protects the children's rights to live, grow, and thrive and forbids parents in killing them. 
Second, a decision which provides only a minimum legal protection towards biological children. In this case, the judge decided that only mothers were accountable for their biological children (see the Decision number Salinan Penetapan Nomor 0403/Pdt.P/2014/ PA.Bjm, 2014; the Decision number Salinan Penetapan Nomor 0043/Pdt.P/2014/PA.JP., 2014). A legal consequence from these decisions is that the legal birth certificate of biological children only mentioned the name of their mothers. As such, only the mothers of the biological children were accountable for rights such as caregiving, education, and inheritance.

From the juridical perspective, this second type of decision is justifiable and is line with the Marriage Law, the Islamic Family Law, and Islamic Sharia doctrine. However, from the perspective of Human Rights Law, Child Welfare Law, and Child Protection Law, this decision is viewed as lacking legal protection and justice. That is, this decision potentially causes socio-psychological problems, especially for the biological children. The children, in particular, will receive a negative labelling from their social environment as illegitimate children. Consequently, the children will unlikely fit in well in their social environment and tend to lose their self-confidence.

Third, a decision that provides considerable legal protection towards the biological children's civil rights (see the Decision number 0078/Pdt.P/2014/PA.Mgt, 2014; the Decision number 0185/Pdt.P/2014/PA.TL, 2014). These two decisions mandated legal protection in which the status of the children's biological fathers was acknowledged legally, with an agreement form their biological mothers (Satrio, 2005, p. 118). Basically, the Citizenship Administration Law of 2013 rules that legal children are those whose parents are married legitimately according to religious law, but not according to government law. Notwithstanding, judges at these religious courts approved the plea to provide a legal standing of the civil relationship between biological children and their fathers in limited ways.

The judges specifically decided that the fathers of their biological children were responsible to fulfill their children living cost and to arrange inheritance by writing a legal will (wasiat wajibah). This consequence was considered as a punishment for the fathers who broke religious norms and government law in regard to having children born out of wedlock. This decision serves three purposes: (1) to provide legal protection and give 
justice to biological children, (2) to ensure that biological children live prosperously, and (3) to warn the adulterer and decrease act of adultery in the society.

Granting the legal standing about the origin of biological children manifests the implementation of Article 55 of Law number 39/1999 about Human Rights. This article clearly states, "every child has the right to know their biological parents, to be raised, and to be looked after by their parents". As such, children born out of wedlock will possess clear legal identity - proven by their legal birth certificate - in which the name of their biological parents are attached in the certificate.

\section{The judges' method of legal reasoning}

Analyses on legal decisions made in five religious courts in this study found that judges applied different methods of legal reasoning, which are considerably subjective. In turn, these different decisions implicated to inequality in terms of protection towards biological children.

The five judges in this study basically departed from a similar perception in which they considered the legality of children as the basis for determining the status of biological children. In their consideration, they applied a systematical interpretative method, that is interpreting existing laws as part of the whole system of law (Mertokusumo \& Pitlo, 1993, p. 59). In this way, they specifically correlate Article 42 Law number 1/1974 about Marriage with Article 99 of the Compilation of Islamic Laws. From the point of view of these laws, they decided that biological children were illegitimate children. However, these judges applied different legal reasonings when deciding the legal civil relationship between biological children and their fathers.

For instance, the Decision number 0316/Pdt.P/2015/PA.Mlg. - in which the plea for the origin of biological children in relation to their parents were denied - indicated the judge's lack of initiative to explore legal sources. In other words, the judge did not seek deeper legal references before deciding to deny the status of biological children in relation to their parents. In this way, it can be said that the judge's decision was in contradiction with Article 5 Paragraph (1) Law number 48/2009, which provides authority to judges for exploring, studying, and synthesizing social values and justice values embedded in the existing laws. 
In different examples, the Decision number 0043/Pdt.P/2014/PA.JP. and the Decision number 0403/Pdt.P/2014/PA.Bjm. showed that the judges similarly applied a systematic interpretative method to decide the legal civil relationship between biological children and their mothers. They mainly based their decisions on Article 43 of the Marriage Law and Article 100 of the Islamic Family Law. It can be argued that these decisions were quite static and normative since they were built upon outdated laws that limited the rights of biological children very strictly. Clearly, the judges who made these decisions did not give appropriate consideration on the Indonesian Constitutional Court Decree number 46/PUU-VIII/2010 and MUI's Fatwa number 11/2012, which provide legal protection towards the civil rights of biological children.

The other two decisions (see the Decision number 0078/Pdt.P/2014/PA.Mgt, 2014; the Decision number 0185/Pdt.P/2014/PA.TL, 2014), on the other hand, demonstrated a novel legal decision. The former decision, for example, indicated how the judge applied a legal construction method in which an abstract, passive, and general law was explored deeper to accommodate a specific case (Hardjon and Djatmiati, 2005, p. 26). In this case, the judge constructed the meaning of civil relationship generally and specifically. From the general perspective, civil relationship means that there is a legal relationship between biological children and their fathers and their fathers' families. As such, the fathers are accountable for the children's civil rights such as inheritance, guardianship, and welfare. From the lex specialis perspective, however, civil relationship for Muslims means that Fathers who have children born out of wedlock are accountable in limited ways. They are specifically responsible for providing living allowance until the children become independent adults and arranging a legal will (wasiat wajibah) for them.

The later decision showed how the judge applied a theological-sociological interpretative approach. In other words, the judge interpreted existing laws by closely scrutinizing the purpose of why the laws were enforced for the benefit of the society. This approach is similar to what is known in Islamic Sharia as maqasidid as-syariah. That is, the interpretation of any Islamic laws should be based on how the laws are purposely enforced and how these implicate to the benefit of the society (Asnawi, 2014, p. 22). The judge specifically used this approach to decide the legal status and the rights of biological children in relation to their 
parents. The judge further argued that Article 43 of the Marriage Law and Article 100 of the Islamic Family Law did not guarantee justice for biological children as far as they only regulated the legal relationship between the children and their mothers.

Referring to Article 7 Law number 23/2002 about Child Protection, the judge in the Religious Court of Trenggalek stated that each child had the right to know their parents despite being a biological child, to be raised by their parents appropriately, and to receive proper education for their self-development and actualization. Therefore, biological fathers were entitled to protecting their biological children and fulfilling their basic needs to assure that their children could grow and participate in the society optimally in accordance with their basic human's rights.

\section{Typologies of judges' legal reasonings}

In general, there are two main approaches of judges' legal reasonings, which are conservative and progressive (Mertokusumo and Pitlo, 1993, p. 5). Notwithstanding, this study found three approaches of legal reasonings as reflected in how the judges in this study made decisions regarding biological children. These include pragmatic approach, conservative approach, and progressive approach.

\section{Pragmatic legal reasoning}

Pragmatic legal reasoning refers to the way a judge tends to use pragmatic thinking or mindset when examining, judging, and concluding a case. A judge with this type of reasoning likely produces literal decisions (Nasution, 2016, p. 6). In other words, they often fail to consider the principle of equality before the law and expediency during the trial.

As reflected in the Decision number 0316/Pdt.P/2015/PA.Mlg., the judge in this case produced a pragmatic decision in which the plea for the status and origin of biological children was denied. By referring to Article 43 of the Marriage Law and Article 100 of the Islamic Family Law, the judge decided that biological children had civil relationship with their mothers only. That is to say that the children did not have legal civil relationship with both of their parents.

It is argued that the judge's legal reasoning in this case is partial. That is, the decision 
made is not coherent with the legal consideration (Efendi, 2018, p. 254), where coherence is critical in any legal reasoning. The judge with a pragmatic mindset tends to overlook the principle of equality before the law. It is likely that they only focus on carrying on the trial and producing timely decision. Their pragmatic legal reasoning is justifiable since it is in accordance with Article 16 Law number 4/2004 about the Authority of Judge. In this article, a judge cannot refuse to examine, conduct trial, and decide a case just because there is a lack of legal references.

\section{Conservative legal reasoning}

From the perspective of law studies, judges who base their decisions on written legal sources as their main references are considered conservative. It is thought that this type of judge tends to interpret legal sources through legal-positivistic lenses. In other words, when examining legal sources, they mainly focus on literal aspects, while common values and norms such as equality are often overlooked since these are invisible to the five senses (Sarmadi, 2012, p. 333). The judges rely heavily on an overt legal law, which often makes them become a 'textual judge'.

A relatively conservative judge is often influenced by legism. Legism is a school of thought in law studies which does not accommodate any other laws except legal laws (Prakoso, 2016, p. 146). As such, legism represents the majority of legal-positivistic approach. When conducting a trial, judges with this kind of mindset follow the existing legal laws rigidly. They do not try to seek for sources other than from textual sources. In other words, they only decide cases which have concrete rational references from the code of law (Rifai, 2014, p. 127).

Judges with a conservative mindset in this study produced decisions in which the children's civil relationship with their mothers was acknowledged while their civil relationship with their fathers were rejected (see the Decision number 0403/Pdt.P/2014/PA.Bjm, 2014; the Decision number 0043/Pdt.P/2014/PA.JP., 2014). These two similar decisions indicated that the judges did not make a sufficient legal effort in providing justice and considering the children's interests. In these two decisions, the judges specifically exempted fathers from their responsibilities towards their biological children.

In addition to legism, the judges' legal reasoning in these two cases was likely built upon 
a deductive logic. That is, their legal reasoning departed from a lens of common legal law that was later used to view a specific case (Rodes and Pospesel, 1997, p. 7). In the deductive logic, legal positivistic norms are used as the primary rules. Consequently, judges consider legal positivistic norms as the major premises and later use them in a specific case as minor premises (Shidarta, 2013, p. 200). In case of biological children in this study, the judges

particularly considered major premises such as Article 42 and 43 of the Marriage Law and Article 99 and 100 of the Islamic Family Law as minor premises when deciding these cases. As a result, biological children were considered as illegitimate children in which they had legal civil relationship with their mothers only.

\section{Progressive legal reasoning}

Progressive legal reasoning refers to a stance which views law and court as means for social changes (Mertokusumo and Pitlo, 1993, p. 5). The concept of progressive law, as suggested by Rahardjo, means finding truth and providing legal protection and civil rights in which biological children supposedly receive. From the progressive perspective, the trial process should not focus on interpreting the code of law textually but focus on contextualizing the code of law in its current spaces and times (Tanya, 2010; Saifullah, 2014).

Due to this, progressive judges are often known as contextual judges. This means that these judges are able to find new legal interpretations when the existing laws are too general, abstract, and irrelevant in the current and dynamic sociocultural contexts. According to Roscoe Pond, advantageous laws are the ones that live amongst the society (as cited by Rahardjo, 2007, p. 165). Departing from this idea, judges' roles are not only to implement existing laws but also to delve into finding new legal interpretations. In other words, they need to be able to compare, contrast, and correlate findings during the trial with the code of law and later synthesize fair decisions.

In this study, legal decisions which were built upon progressive legal reasoning were apparent (see the Decision number 0078/Pdt.P/2014/PA.Mgt, 2014; the Decision number 0185/Pdt.P/2014/PA.TL, 2014). In these two decisions, a plea for the origin of biological children in relation to their parents was approved. The judges specifically considered the sociocultural contexts surrounding the cases in addition to scrutinizing the code of law. In 
particular, the judges based their decisions on two combinations of laws. First, in deciding the origin of biological children, the judges referred to Article number 1/1974 about Marriage, the Islamic Family Law, and MUI's Fatwa number 11/2012 as the basis for their juridical considerations. The judges used these laws to differentiate the legal status and civil rights between legitimate children and illegitimate children. On the other hand, the judges referred to the 1945 Constitution, the Indonesian Constitutional Court Decree number 46/PUUVIII/2010, Law number 23/2002 about Child Protection, Law number 39/1999 about Human Rights, Law number 4/1979 about Child Welfare, and MUI's Fatwa number 11/2012 as juridical considerations to protect and assure the biological children's civil rights.

In the case of these two decisions, the judges were able to further explore legal sources which discussed the civil rights of biological children as well as to consider the sociocultural contexts in which the children lived. The judges in particular argued that it did not reflect the principle of justice when biological children had to lose their civil rights for the wrongdoings done by their fathers. By referring to the Constitutional Court's Decree, the judges progressively attempted to assure that justice was served, and these cases became a public lesson. Despite being progressive, the judges also maintained religious principles as stated in Islamic sharia.

The main implication that emerged from these two decisions was that the biological children's relationship with their parents was legally acknowledged. However, the legal relationship between biological children and their fathers was somehow limited. That is, the fathers were accountable only for fulfilling the children's living cost and writing a legal will (wasiat wajibah). This legal acknowledgment was absent in the Article number 1/1974 about Marriage and the Islamic Family Law. Additionally, this was not in accordance with Article 49 Paragraph (1) and (2) Law number 24/2013 about Citizenship Administration, which considered legitimate children only those who were born in wedlock. As such, the judges in these two cases had produced a legal breakthrough when acknowledging the status of biological children as well as their civil rights.

The regulation regarding legal will (wasiat wajibah) is actually mentioned in Article 209 of the Islamic Family Law, where one third of total fortune can be inherited. However, this regulation is only applicable for adopted children. This regulation is aimed at assuring that adopted children receive sufficient welfare, and it is in line with the public interests (Junaidi, 2013, p. 92). 
The authors of this study agree with Faiq Tobroni who stated that progressive legal reasoning in the case of biological children indicated a moderation of law. This means that the judges in these cases were able to draw a middle ground between conservative laws and liberal laws in deciding the legal status of biological children. In particular, liberal laws were taken into account as a rationale for maintaining the universal declaration of human rights. On the other hand, conservative laws were also considered to preserve the sacredness of religious laws, which view human rights from a relativistic perspective (Tobroni, 2018, p. 324). As such, the legal construction built by the progressive judges in this study was by providing legal protection towards biological children's civil rights while at the same time maintaining the sacredness of marriage in accordance with Islamic laws. The judges' moderate stance is in congruent with Law number 7/1989 which states that religious courts' main role is to uphold justice for Muslim that is based on Islamic laws.

The judges in these two cases did not use the term "illegitimate children", as commonly used in the MUI's Fatwa number 11/2012 and Islamic jurisprudence literature, to label children born out of wedlock. They argued that this labelling could hurt the children's feeling. Thus, using the term biological children was more favorable for them. The use of the term biological children is in line with Ibn Abidin's conception in which he categorizes children born out of wedlock as true children (al-walad al-haqiqiy). In his defense, Ibn Abidin argues that children born out of wedlock are humans (makhlüqah) who are originated from the sperm of their biological fathers (Abidin, 2003, p. 12).

Additionally, these judges showed how they could find a balance between norms stated in the code of law and living law. Specifically, they were able to use two logical reasonings simultaneously, which were inductive logic and deductive logic. They employed inductive logic as a lens to investigate empirical studies regarding biological children in the society. Meanwhile, deductive logic was used as a lens to explore authoritative legal sources in relation to biological children.

The judges' decision for not acknowledging the lineage relationship between biological children and their fathers indicated their awareness of religious laws. They argued that this decision was necessary to avoid any negative implications in the future (sädd al-dharìah). According to Ibrahim Hosen, sādd al-dharìah should be applied to any case which could 
endanger religious principles and the society in general (Nafis, 1995, p. 272). The judges likely considered a religious principle in which legitimate children could only be acknowledged from a legitimate marriage. This principle is stated in the Quran Surah Al-Furqon verse 54, "It is He who has created man from water; then has He established relationships on lineage and marriage; for thy Lord has power (over all things)".

The decision to acknowledge a legal relationship between children born out of wedlock with their biological fathers is justifiable as long as it does not contradict with the concept of lineage in Islam (Nurlaelawati and Van Huis, 2019). However, acknowledging a lineage relationship is still a problematic issue in Islam as it undermines the sacredness of marriage. It is also feared that this acknowledgment can trigger adultery which causes someone to lose their lineage status and dignity.

The lack of lineage relationship between biological children and their fathers has a direct implication to the absence of guardianship and inheritance between the two parties. A substantial number of Islamic scholars and Muslims in common agree with this conception. They similarly argue that this conception is rooted in robust and reliable Islamic sources and is more likely relevant to be applied in Indonesia whose majority of its population is Muslims.

For the sake of common interest, the progressive judges in this study tried to accommodate both the legitimation of marriage and the children's civil rights. Particularly, judges in religious courts of Magetan and Trenggalek granted the civil rights of biological children proportionally in accordance with the code of law and living law. They specifically assured that the biological children's civil rights were acknowledged, respected, and protected. In addition to providing legal certainty, this assurance was in accordance with the declaration of human rights, universal welfare, and the principles of justice upheld by a state law (Sidharta, 2004, pp. 124-125).

The decisions made by judges in Magetan and Trenggalek are similar to legal decisions made in Morocco. Morocco's courts rule that biological children cannot have a lineage relationship with their fathers. However, the fathers can take a legal action to acknowledge the legal status of their biological children by presenting robust evidence before the court (Schlumpf, 2016, p. 10). Unlike courts in Indonesia and Morocco, courts in Malaysia mostly refer to Islamic jurisprudence rigidly in the case of biological children. For instance, 
ljtihad: Jurnal Wacana Hukum Islam dan Kemanusiaan, Volume 21, No. 1, Juni 2021: 1-19

biological children whose parents get married after they were born cannot change their legal status and thus lose their civil rights (Bakar et al., 2017, p. 9).

\section{Conclusion}

This study found various legal decisions made by religious courts in Indonesia regarding the origin of biological children. There are at least three types of legal reasoning. First, pragmatic judges decided to reject parents' legal action to acknowledge their biological children. Due to this rejection, there was a lack of legal protection towards biological children. Second, conservative judges, who were likely influenced by legism, acknowledged that only mothers who had a legal relationship with their biological children. This decision was thought to be lacking fairness and only provided a minimum benefit to biological children. Third, progressive judges produced a decision that assured sufficient protection towards biological children. In this case, children born out of wedlock was legally considered as the biological children of both their fathers and mothers. Additionally, biological fathers were accountable for their children's civil rights such as providing living cost and writing a legal will (wasiat wajibah).

Progressive judges' legal reasoning was based on principles that were oriented for the benefit of mankind. Progressive judges contended that although biological children did not have a lineage relationship with their fathers, they had the right to have a civil relationship with them. The use of the term "biological children" to refer to children born out of wedlock by the progressive judges demonstrated a critical acknowledgment in which justice was served for these children in particular and for the society in general. As such, this progressive legal reasoning has a significant contribution to the development of the study of Islamic law in Indonesia, especially regarding the protection of biological children's civil rights.

This study was limited to exploring the different legal reasonings with regard to the status of children born out of wedlock and their civil rights based on legal decisions in five religious courts in Indonesia. Further empirical studies are needed to examine factors that contribute to the disparities of judges' legal reasonings more comprehensively. These further studies are necessary to capture the complexity of legal decisions in religious courts regarding the origin of biological children. With more understanding of this complexity, it is hoped that the effort to provide protection, legal certainty, justice, and well-being towards biological children can be achieved optimally. 
Legal reasonings of religious court judges in deciding the origin of children: ...(Rohmawati, Ahmad Rofiq)

\section{Bibliography}

Abidin, I. (2003) Radd al-Mubtār 'Alā ad-Dur al-Mukhtār Syarh Tanwīr al-Abșār, Jilid IV. Riyadh: Dār 'Alam al-Kutub.

Adji, O. S. (1984) Hukum Hakim Pidana. Jakarta: Penerbit Erlangga.

Al-Zuhaily, W. (1985) Al-Fiqh al-Islämi wa 'Adillatuh, Jilid VIII. Beirut: Dar al-Fikr.

Asnawi, M. N. (2014) Hermeneutika Putusan Hakim: Pendekatan Multidisipliner dalam Memahami Putusan Peradilan Perdata. Yogyakarta: UII Press.

Bakar, A. et al. (2017) 'Registration Problems of Illegitimate Children among Muslims in Malaysia', Journal of Islamic Studies and Culture, 5(1), pp. 9-15.

Banjarmasin, P. A. (2014) Salinan Penetapan Nomor 0403/Pdt.P/2014/PA.Bjm. Indonesia:

Direktori Putusan Mahkamah Agung Republik Indonesia. Available at: putusan. mahkamahagung.go.id.

Butt, S. (2012) 'Asia Pasific "Illegitimate” Children and Inheritance in Indonesia', Legal Studies Research Paper, 12(63).

Efendi, J. (2018) Rekonstruksi Dasar Pertimbangan Hukum Hakim Berbasis Nilai-Nilai Hukum dan Rasa Keadilan yang Hidup dalam Masyarakat. Depok: Prenadamedia Group.

Hardjon, P. M. and Djatmiati, T. S. (2005) Argumentasi Hukum. Yogyakarta: Gajahmada University Press.

Ilma, M. (2016) Penetapan Hakim Tentang Asal Usul Anak Pasca Putusan Mabkamah Konstitusi Nomor 46/PUU-VIII/ 2010 (Studi Kasus di Pengadilan Agama Bantul). Yogyakarta.

Indonesia, K. Y. R. (2014) Disparitas Putusan Hakim Ïdentifikasi dan Implikasi. Jakarta.

Junaidi, A. (2013) Wasiat Wajibah: Pergumulan antara Hukum Adat dan Hukum Islam di Indonesia. Yogyakarta: Pustaka Pelajar.

Magetan, P. A. (2014) Salinan Penetapan Nomor 0078/Pdt.P/2014/PA.Mgt. Indonesia: Direktori Putusan Mahkamah Agung Republik Indonesia. Available at: putusan. mahkamahagung.go.id.

Malang, P. A. (2015) Salinan Penetapan Nomor 0316/Pdt.P/2015/PA.Mlg. Indonesia: Direktori Putusan Mahkamah Agung Republik Indonesia. Available at: putusan. mahkamahagung.go.id.

Marilang (2016) 'Legal Relationship Between Illegitimate Children and Their Biological 
ljtihad: Jurnal Wacana Hukum Islam dan Kemanusiaan, Volume 21, No. 1, Juni 2021: 1-19

Father: The Analysis of Constitutional Court Decree No. 46/PUU-VIII/2010 in the Perspective of Civil and Islamic Law', Journal Of Indonesian Islam, 10(2), pp. 335-354. Mertokusumo, S. and Pitlo, A. (1993) Bab-Bab tentang Penemuan Hukum. Bandung: Citra Aditya Bakti.

Mokoginta, B. (2017) Perlindungan Hak-Hak Keperdataan Anak Luar Kawin Dalam UU No. 1 Tahun 1974 Tentang Perkawinan Pasca Putusan Mabkamah Konstitusi No. 46/PUUVIII/2010. UIN Sunan Kalijaga Yogyakarta.

Nafis, M. W. (1995) Kontekstualisasi Ajaran Islam. Jakarta: IPHI-Paramadina.

Nasution, K. (2016) 'Perlindungan terhadap Anak dalam Hukum Keluarga Islam Indonesia', Al-'Adalah, 13(1), pp. 1-10.

Nurlaelawati, E. and Van Huis, S. C. (2019) 'The Status of Children Born Out of Wedlock and Adopted Children in Indonesia: Interactions Between Islamic, Adat, and Human Rights Norms', Journal of Law and Religion, 34(3), pp. 356-382.

Prakoso, A. (2016) Penemuan Hukum: Sistem, Metode, Aliran dan Prosedur dalam Menemukan Hukum. Yogyakarta: LaksBang PRESSindo.

Pusat, P. A. J. (2014) Salinan Penetapan Nomor0043/Pdt.P/2014/PA.JP. Indonesia: Direktori Putusan Mahkamah Agung Republik Indonesia. Available at: putusan.mahkamahagung.go.id.

Rahardjo, S. (2007) Membedah Hukum Progresif. Jakarta: Kompas.

Rifai, A. (2014) Penemuan Hukum Oleh Hakim, Dalam Perspektif Hukum Progresif. Jakarta: Sinar Grafika.

Rodes, R. E. J. and Pospesel, H. (1997) Premises and Conclusions, Symbolic Logic for Legal Analysis. New Yersey: Prentice Hall.

Rosyad, S. (2017) 'Status Hukum Anak di Luar Perkawinan dalam Hukum Islam dan Implementasinya dalam Perkembangan Peraturan Perundang-Undangan di Indonesia (Studi Tentang Putusan Mahkamah Konstitusi)', Jurnal Hukum Islam, 15(1), pp. 155-179. Saifullah (2014) 'Kajian Kritis Teori Hukum Progresif Terhadap Status Anak Luar Nikah Dalam Putusan Mahkamah Konstitusi No. 46/PUU-VIII/2010', Al-Manahij, 8(2). Sarifudin (2015) Teori Maslahat At-Tufi dan Penerapannya, Dalam Analisis Kasus Putusan Mahkamah Konstitusi Nomor 46/PUU-VIII/ 2010 tentang Status Anak di Luar Perkawinan. UIN Sunan Kalijaga Yogyakarta. 
Legal reasonings of religious court judges in deciding the origin of children: ...(Rohmawati, Ahmad Rofiq)

Sarmadi, A. S. (2012) 'Membebaskan Positivisme Hukum Ke Ranah Hukum Progresif (Studi Pembacaan Teks Hukum Bagi Penegak Hukum)', Jurnal Dinamika Hukum, 12(2).

Satrio, J. (2005) Hukum Keluarga tentang Anak dalam Undang-Undang. Bandung: Alumni.

Schlumpf, E. (2016) 'The Legal Status of Children Born Out of Wedlock in Morocco', Electronic Journal of Islamic and Middle Eastern Law (EJIMS), 4, pp. 1-26.

Shidarta (2013) Hukum Penalaran dan Penalaran Hukum: Akar Filosofis. 1st edn. Yogyakarta: Genta Publishing.

Sidharta, B. A. (2004) 'Kajian Kefilsafatan tentang Negara Hukum', Jurnal Hukum Jentera, , Pusat Studi Hukum dan Kebijakan (PSHK), Jakarta, 3(2).

Sujono, I. N. (2015) Kedudukan Hukum Anak Luar Kawin dalam Perspektif Putusan Mabkamah Konstitusi Nomor/46/PUU-VIII/2010. Surabaya: Aswaja Pressindo.

Tanya, B. L. (2010) Teori Hukum, Strategi Tertib Manusia Lintas Ruang dan Generasi. Yogyakarta: Genta Publishing.

Tobroni, F. (2018) 'Asas Proporsionalitas Sebagai Moderasi Pandangan Hukum Diametral (Kajian Putusan Nomor 0156/Pdt.P/2013/PA.JS)', Jurnal Yudisial, 11(3), pp. 307-325.

Trenggalek, P. A. (2014) Salinan Penetapan Nomor 0185/Pdt.P/2014/PA.TL. Indonesia: Direktori Putusan Mahkamah Agung Republik Indonesia. Available at: putusan. mahkamahagung.go.id.

Usma, R. (2019) Hukum Pencatatan Sipil. Jakarta: Sinar Grafika.

Wahyudi, M. . (2017) 'Judges’ Legal Reasoning on Child Protection: Analysis of Religious Courts' Decisions on the Case of Child Parentage', Al-Jami'ah: Journal of Islamic Studies, 55(1), pp. 127-154. 
